\title{
Impact of DNA Repair Gene Polymorphisms (XPD and XRCC1) on the Risk of Breast Cancer in Egyptian Female Patients
}

\author{
Yousry Mostafa Hussien ${ }^{1}$, Amal F. Gharib ${ }^{1}$, Hanan A. Awad MD ${ }^{1}$, \\ Rehab A. Karam ${ }^{1}$ and Wael H. Elsawy'. \\ ${ }^{1}$ Department of Medical Biochemistry, ${ }^{2}$ Department of Oncology, \\ Faculty of Medicine, Zagazig University, Zagazig, Egypt
}

\begin{abstract}
The genes involved in DNA repair system play a crucial role in the protection against mutations. It has been hypothesized that functional deficiencies in highly conserved $D N A$ repair processes resulting from polymorphic variation may increase genetic susceptibility to breast cancer. There are multiple pathways to repair the different types of DNA damage and maintain genomic integrity among them is the nucleotide excision repair (NER) and the base excision repair (BER) pathways. Aim \& methods: The aim of the present study was to examine the relation between the DNA repair gene polymorphisms and breast cancer $(B C)$ risk in Egyptian females and to analyze their relation to clinico-pathological parameters of $B C$ and also to investigate the synergistic effect of both genes on BC susceptibility. Both XPD and XRCC1 polymorphisms were characterized in 100 BC Egyptian females and 100 healthy women who had no history of any malignancy by amplification refractory mutation system -polymerase chain reaction (PCR) (ARMS) method and PCR with confronting two-pair primers $(P C R-C T P P)$, using DNA from peripheral blood in a case control study. RESULTS: our results revealed that the frequencies of AA genotype of XPD codon 312 polymorphism were significantly higher in the breast cancer study patients than in the normal individuals $(p \leq 0.003)$, and did not observe any association between the XRCC1 Arg399Gln polymorphism and risk of developing breast cancer Also, no association between both XPD Asp312Asn and XRCC1 A399G polymorphisms and the clinical characteristics of disease Finally, the combination of $A A(X P D)+A G(X R C C 1)$ were significantly associated with breast cancer risk. In conclusion, the present results suggest that, XPD gene is an important candidate gene for susceptibility to breast cancer. Also, gene-gene interaction between $X P D(A A)+X R C C 1(A G)$ polymorphism may be associated with increased risk of breast cancer in Egyptian women.
\end{abstract}

Keywords: nucleotide excision repair, base excision repair, breast cancer, XPD, XRCC1.

\section{INTRODUCTION}

Breast cancer remains the most frequent cancer and the second leading cause of cancer death among women in the world ${ }^{[1]}$. In Egypt, It accounts for nearly $35.1 \%$ of cancers among the Egypt National Cancer 
Institute patients [2] with an ageadjusted incidence rate of 49.6/100 000 population ${ }^{[3]}$ and an increase of about 11 folds in breast cancer incidence rate between 1972 and $2001^{[4]}$.

Cells of the body constantly exposed to mutagenic assault from radiation, chemical carcinogens, alcohol, estrogen, and diet, which produce reactive oxygen species, oxidized bases, bulky DNA adducts, and DNA strand breaks. Unrepaired or misrepaired DNA may lead to deletions, amplifications, and/or mutations of critical genes that contribute to breast carcinogenesis ${ }^{[5]}$.

There are multiple pathways to repair the different types of DNA damage and maintain genomic integrity. Among these pathways is nucleotide excision repair (NER) pathway that repairs a wide variety of DNA damage, including cross-links, oxidative damage and bulky adducts and the base excision repair (BER) pathway that repair small lesions such as oxidized or reduced bases, fragmented or non bulky adducts, and lesions caused by methylating agents $^{[6]}$.

There are over 100 identified DNA repair genes (protecting genes) and most of them are known to have genetic variation in humans ${ }^{[7]}$. DNA repair gene polymorphisms may alter the protein function and cause reduction in DNA repair capacity that may lead to genetic instability and carcinogenesis ${ }^{[8,9]}$.

The XPD (xeroderma pigmentosium group D) protein participates in NER as it represent an integral member of the basal transcription factor BTF2/TFIIH complex, which is a multi-protein with functions including transcription, NER, transcription-coupled repair, apoptosis, and cell cycle regulation. Also, the XPD gene product has an ATP-dependent DNA helicase activity [10]. Single nucleotide polymorphisms (SNPs) have been identified in several exons of the XPD gene (NER), among which one in codon 312 of exon 10 and the other in codon 751 of exon 23 are commonly studied and result in amino acid changes (Asp312Asn and Lys751Gln, respectively) ${ }^{[11]}$. These polymorphisms are associated with lower DNA repair capacity and a higher level of DNA adducts ${ }^{[11,12]}$.

XRCC1 (X-ray repair crosscomplementing group 1) is known to participate in base excision repair (BER). The XRCC1 is a multidomain protein that has no known catalytic activity itself but links with a scaffolding protein that associated with other proteins such as DNA polymerase $\beta$, DNA ligase III and poly(ADP-ribose) polymerase (PARP) that are needed at the site of DNA damage ${ }^{[13] .}$

The XRCC1 Arg399Gln polymorphism is located in the area coding for a PARP binding site. PARP is a zinc-finger containing enzyme that detects DNA strand breaks. Arg399Gln is nonconservative amino acid changes and occur in evolutionarily conserved regions. That is, the wild-type and variant residues have dissimilar physical and/or chemical properties, suggesting that these substitutions may affect protein structure and potentially have functional relevance ${ }^{[14]}$. 
Because DNA damages are repaired by multiple repair pathways, a genetic variant in multiple repair pathways may have synergistic effect on breast cancer risk. The aim of the present study was to evaluate the association of genetic polymorphisms in 2 DNA repair pathways, XPD (Asp312Asn) as NER and XRCC1(A399G) as BER, with breast cancer susceptibility. We further investigate the potential combined effect of these DNA repair variants on breast cancer risk.

\section{SUBJECTS \& METHODS}

\section{Subjects:}

The current study included one hundred Egyptian women (mean age $50.5 \pm 9.8$ years), with histologically proven diagnosis of $\mathrm{BC}$ between January 2009 and June 2010, they were among the attendants of Surgical Clinics of Zagazig University Hospital at Sharkia, Egypt. The control group were 100 age- matched women (mean age 51.2 \pm 11.4 ) with no signs or symptoms of malignancy, they were randomly selected from various clinics at Sharkia, Egypt. The clinicopathological features of the patients and controls were summarized in Table 1. BC cases were graded according to the modified criteria as described by Bloom and Richardson $^{[15]}$, and they were staged according to the American Joint Committee on Cancer (AJCC) staging system ${ }^{[16]}$.

The study protocol was approved by the ethical committee of Faculty of Medicine, Zagazig University, and informed consent for the experimental use of specimens was obtained from all participants.

Table 1: The clinicopathological features of breast cancer patients $(n=100)$.

\begin{tabular}{l|l}
\hline Patient characteristic & Number \\
\hline Age (years) & $50.5 \pm 9.8$ \\
$\leq 50$ & 67 \\
$51-60$ & 33 \\
Tumor size & 54 \\
T1 $\leq 2 \mathrm{~cm})$ & 27 \\
T2 $(>2 \mathrm{~cm}-5 \mathrm{~cm})$ & 13 \\
T3 $>5 \mathrm{~cm})$ & 6 \\
T4 (tumor of any size that has broken through (ulcerated) the skin, & \\
or is attached to the chest wall) & 52 \\
Lymph node status & 48 \\
N0 & 40 \\
N1 & 35 \\
AJCC Pathological stage & 14 \\
I & 11 \\
II & \\
III & 18 \\
IV & 52 \\
Histological grade (modified Bloom-Richardson score) & 30 \\
I (Well differentiated) & \\
II(Moderately differentiated) & \\
III(Poorly differentiated) & \\
\hline
\end{tabular}


Blood sample collection:

Half- ml of Blood was collected in EDTA-treated tubes for DNA extraction, and one $\mathrm{ml}$ in plain tube for serum separation for CA15.3 and CEA assay.

Measurement of CEA and CA15.3:

Serum levels of CEA and CA15.3 were measured by an enzyme-linked immunosorbent assay (ELISA) in duplicate using ELISA commercial kit (DRG Diagnostics, GmbH, Germany) according to the manufacturer's instructions. The assay employs the quantitative sandwich enzyme immunoassay technique.

\section{DNA preparation and genotype} analysis:

EDTA-blood samples were obtained from all participants, coded and analyzed in a blind manner for genomic DNA extraction using QIAGEN genomic DNA extraction kit (QIAGEN, Clinilab, Egypt) as described in the user manual. The quality of the genomic DNA was tested using agarose gel electrophoresis.

Samples were genotyped for detecting SNP OF XPD codon 312 and XRCC1 codon 399 in genomic DNA.PCR, for both polymorphisms, was performed in a final volume of 25 $\mu \mathrm{l}$ containing $100 \mathrm{ng}$ of genomic DNA, 1X PCR mix (20mM Tris-HCl, $\mathrm{pH} 8.3,50 \mathrm{mM} \mathrm{KCl}, 1.5 \mathrm{mM} \mathrm{MgCl}_{2}$, $0.3 \mathrm{mM}$ dNTPs and $2 \mathrm{U}$ Taq DNA polymerase) and $0.2 \mu \mathrm{M}$ of each primer .The amplification was carried out using a PTC-100 thermal cycler (MJ Research, Inc., Watertown, Massachusetts, USA).

A tetra-primer amplification refractory mutation system (ARMS)- polymerase chain reaction (PCR) assay was used for detection of XPD codon 312 polymorphism as described by Rybicki et al. (2004) ${ }^{[17]}$, The ARMS assay is an allele-specific PCR method that uses two primers, each with the $3^{\prime}$ terminal base complementary to one of the alleles to be identified. An internal control primer pair was included in each reaction (ARMSA: 5'-CCC ACC TTC CCC TCT CTC CAG GCA AAT GGG-3'; ARMSB: 5'-GGG CCT CAG TCC CAA CAT GGC TAA GAG GTG-3') at a 1:5 dilution relative to the allele-specific primers. A 150-bp PCR fragment was generated with the following primers: reverse primer 5'-CAG GAT CAA AGA GAC AGA CGA GCA GCG C3'; G allele forward specific primer 5'GTC GGG GCT CAC CCT GCA GCA CTT CGG C-3'; A allele forward specific primer 5'-GTC GGG GCT CAC CCT GCA GCA CTT CGA T-3'. Cycling conditions were initial denaturation of $94{ }^{\circ} \mathrm{C}$ for $5 \mathrm{~min}$, followed by 35 cycles of $30 \mathrm{~s}$ at $94{ }^{\circ} \mathrm{C}, 30 \mathrm{~s}$ at $61^{\circ} \mathrm{C}$ and $50 \mathrm{~s}$ at $72{ }^{\circ} \mathrm{C}$ and finally $7 \mathrm{~min}$ at $72{ }^{\circ} \mathrm{C}$.

The amplified products were analyzed on $2 \%$ agarose gels stained with ethidium bromide. Genotypes were typed as GG and AA depending on the development of bands when primers specific for allele $\mathrm{G}$ (as GG) or allele A (as AA) were used. Samples were typed as heterozygotes (GA) when bands were seen with both the primers (Fig. 1).

PCR-CTPP (PCR with confronting two-pair primers) method was performed for detecting the XRCC1 codon 399 variantas 
descriped by Ito et al. (2004) ${ }^{[18]}$. The extracted DNA was amplified with the four primers by ' $\mathrm{F} 1,5$ '-TCC CTG CGC CGC TGC AGT TTC T-3'; R1, 5'-TGG CGT GTG AGG CCT TAC CTC C-3'; F2, 5'-TCG GCG GCT GCC CTC CCA-3'; and R2, 5'-AGC CCT CTG TGA CCT CCC AGG C3'. PCR conditions were 1-min denaturation at $94^{\circ} \mathrm{C}$ followed by 30 cycles of $94^{\circ} \mathrm{C}$ for $1 \mathrm{~min}, 59^{\circ} \mathrm{C}$ for 1 min, and $72^{\circ} \mathrm{C}$ for $1 \mathrm{~min}$, with a 10 min extension at $72^{\circ} \mathrm{C}$. Primer pairs $\mathrm{F} 1$ and $\mathrm{R} 1$ for the $\mathrm{G}$ allele (399Arg) and $\mathrm{F} 2$ and $\mathrm{R} 2$ for the $\mathrm{A}$ allele (399Gin) produced allele-specific bands of 447- and 222-bp, respectively, as well as a 630-bp common band (Fig. 2).

\section{Statistical Analysis}

Statistical analysis was done using the Statistical Package for Social Sciences version 11 (SPSS Inc., Chicago, USA). The significance of association between the observed and expected number of the genotypes for a population in the HardyWeinberg equilibrium was analyzed using the Pearson's two-sided chisquare test. The differences of genotype and allele frequencies between the cases and controls were determined using Chi-square $\left(\mathrm{X}^{2}\right)$ test. The associations between genotypes and $\mathrm{BC}$ risk were analyzed by calculating the crude Odds Ratios (OR) and 95\% Confidence Intervals (CI) by logistic regression method. The adjusted odds ratio was calculated using the multivariate logistic regression method with an adjustment for age. $\mathrm{P}$ value of $<0.05$ was considered statistically significant.

\section{RESULTS}

\section{CEA and CA15.3 assay and BC risks}

In the breast cancer patients the CEA ranged from 4.5 to $8.5 \mathrm{ng} / \mathrm{ml}$, with a mean value \pm SD $(6.7 \pm 0.13$ $\mathrm{ng} / \mathrm{ml}$ ), while in the control group CEA ranged from $2.5-3.1 \mathrm{ng} / \mathrm{ml}$ with a mean value of $2.8 \pm 0.01 \mathrm{ng} / \mathrm{ml}$, there was significant difference as regard CEA levels $(\mathrm{P}<0.001)$.

As regard CA15.3 there was significant difference between breast cancer cases and the control group $(\mathrm{P}<0.001)$, as the mean level of $\mathrm{CA} 15.3 \pm \mathrm{SD}$ in the cases was $66.24 \pm 1.27 \mathrm{IU} / 1$ with a range of $42-86$ IU/1, while in the control group CA15.3 ranged from 2.5 to $3.1 \mathrm{IU} / 1$, with a mean value \pm SD of $2.8 \pm 0.02$ IU/l. Table 2

Table 2: The serum levels of CEA and CA15.3 in breast cancer patients $(n=100)$ and in the control subjects $(n=100)$.

\begin{tabular}{|c|c|c|c|}
\hline $\begin{array}{l}\text { Parameters } \\
(\text { Mean } \pm \text { SD) }\end{array}$ & $\begin{array}{l}\text { Breast cancer patients } \\
(n=100)\end{array}$ & $\begin{array}{l}\text { Control subjects } \\
(n=100)\end{array}$ & p-value \\
\hline CEA(ng/ml) & $6.7 \pm 0.13$ & $2.8 \pm 0.01$ & $\mathrm{P}<0.001$ \\
\hline CA15.3(IU/1) & $66.24 \pm 1.27$ & $2.8 \pm 0.02$ & $\mathrm{P}<0.001$ \\
\hline
\end{tabular}




\section{XPD Asp312Asn polymorphism and $\mathrm{BC}$ risk}

The genotype frequencies of homozygous (GG), heterozygous (AG), and homozygous mutated (AA) were $12 \%, 45 \%$, and $43 \%$ in patients with $\mathrm{BC}$ respectively; and $25 \%, 50 \%$, and $25 \%$ in controls respectively.

The frequency of $\mathrm{A}$ allele was $65.5 \%$ in BC patients and $50 \%$ in controls. These data suggest that the A allele was significantly associated with an increased risk of $\mathrm{BC}$ (ORadj: $1.8,95 \%$ CI, 1.2-2.8) $(\mathrm{P}=0.002)$. The homozygous mutant genotype (AA) significantly increased the risk of $\mathrm{BC}$ (ORadj: 3.5, 95\% CI, 1.5-8.3) $(\mathrm{P}=0.003)$ in comparison with those with (GG) genotype. However, the (AG) genotype showed no significant difference between patients and control groups $(\mathrm{p}=0.08)$ (ORadj: 1.8, 95\% CI, 0.8-4.1).

AA genotype increased the risk of $\mathrm{BC}$ by $(2.26 \mathrm{CI}=1.2-4.1)$ between pts and control group. The distribution of XPD Asp312Asn allele and genotype frequencies in breast cancer patients and the control subjects are represented in Table 3.

Table 3: Distribution of XPD Asp312Asn allele and genotype frequencies in breast cancer patients $(\mathrm{n}=100)$ and the control subjects $(\mathrm{n}=100)$

\begin{tabular}{l|llll}
\hline GENOTYPE & $\begin{array}{l}\text { Breast cancer } \\
\text { patients } n(\%)\end{array}$ & $\begin{array}{l}\text { Control subjects } \\
n(\%)\end{array}$ & $\begin{array}{l}\text { Adjusted OR } \\
(95 \% \text { CI })\end{array}$ & $P^{*}$ \\
\hline GG(ref) & $12(12 \%)$ & $25(25 \%)$ & & \\
AG & $45(45 \%)$ & $50(50 \%)$ & $1.8(0.8-4.1)$ & 0.08 \\
AA & $43(43 \%)$ & $25(25 \%)$ & $3.5(1.5-8.3)$ & $0.003 * *$ \\
G Allele & $69(34.5 \%)$ & $100(50 \%)$ & $1.8(1.2-2.8)$ & $0.002 * *$ \\
A allele & $131(65.5 \%)$ & $100(50 \%)$ & & \\
\hline
\end{tabular}

* calculated by Chi Square test; Adjusted OR=Odds Ratio was adjusted to the age, $95 \% \mathrm{CI}=95 \%$ confidence interval.

\section{XRCC1 A399G polymorphism and BC risk}

The genotype frequencies of homozygous (AA), heterozygous $(\mathrm{AG})$, and homozygous mutated (GG) were $37 \%, 51 \%$, and $12 \%$ in patients with $\mathrm{BC}$ respectively; and 50\%, 40\%, and $10 \%$ in controls respectively.

The frequency of $\mathrm{G}$ (mutant) allele was $37.5 \%$ in $\mathrm{BC}$ patients and $30 \%$ in controls. However, that difference didn't show statistical significant difference between patients and control groups (ORadj: 1.4, 95\% CI, 0.9-2.1 $\quad(\mathrm{P}=0.06)$ The homozygous mutant genotype (GG) and the heterozygous (AG) genotype showed no significant difference in patients and control groups $(\mathrm{p}=0.3)$ (ORadj: 1.6 95\% CI, 0.6-4.1).and ( $\mathrm{p}=0.07)$ (ORadj: 1.7 95\% CI, 0.93.1 ) in relation to (AA) genotype. The distribution of XRCC1 A399G allele and genotype frequencies in breast cancer patients and the control subjects are represented in Table 4. 
Table 4:Distribution of XRCC1 A399G allele and genotype frequencies in breast cancer patients $(\mathrm{n}=100)$ and the control subjects $(\mathrm{n}=100)$

\begin{tabular}{l|llll}
\hline GENOTYPE & $\begin{array}{l}\text { Breast cancer } \\
\text { patients n (\%) }\end{array}$ & $\begin{array}{l}\text { Control subjects } \\
\text { n (\%) }\end{array}$ & $\begin{array}{l}\text { Adjusted OR } \\
(95 \% \text { CI) }\end{array}$ & P $^{\boldsymbol{x}}$ \\
\hline AA(ref) & $37(37 \%)$ & $50(50 \%)$ & & \\
AG & $51(51 \%)$ & $40(40 \%)$ & $1.7(0.9-3.1)$ & 0.07 \\
GG & $12(12 \%)$ & $10(10 \%)$ & $1.6(0.6-4.1)$ & 0.3 \\
GG+AG & $63(63)$ & $50(50 \%)$ & $1.7(0.9-2.9)$ & 0.06 \\
A allele & $125(62.5 \%)$ & $140(70 \%)$ & $1.4(0.9-2.1)$ & 0.06 \\
G Allele & $75(37.5 \%)$ & $60(30 \%)$ & & \\
\hline
\end{tabular}

${ }^{x}$ calculated by Chi Square test; Adjusted $\mathrm{OR}=$ Odds Ratio was adjusted to the age, $95 \% \mathrm{CI}=95 \%$ confidence interval.

Polymorphism in XPD Asp312Asn and XRCC1 A399G and BC risk

Regarding the association of combined polymorphism in XPD Asp312Asn and XRCC1 A399G and the risk of development of $\mathrm{BC}$, the $\mathrm{GG}(\mathrm{XPD})+\mathrm{AA}(\mathrm{XRCC} 1)$ wild type genotype were taken as references. The analysis showed that the AA(XPD)+AG(XRCC1)

combination were significantly associated with breast cancer risk (ORadj: 3.36 95\% CI, 0.9-11.3).and $(\mathrm{p}=0.04)$. However no association were found between other compound polymorphisms and breast cancer risk (no significant difference between patients and control group. the distribution of combined polymorphism among patients and control groups are represented in table 5.

Table 5: Distribution of combined polymorphism among patients ad control groups

\begin{tabular}{|c|c|c|c|c|c|}
\hline $\begin{array}{l}\text { GENOTYPE } \\
\text { XPD }\end{array}$ & XRCC1 & $\begin{array}{l}\text { PATIENTS } \\
\text { n (\%) }\end{array}$ & $\begin{array}{l}\text { CONTROL } \\
n(\%)\end{array}$ & $\begin{array}{l}\text { Adjusted OR } \\
(95 \% \text { CI) }\end{array}$ & $\bar{P}^{x}$ \\
\hline $\mathrm{GG}$ & $\mathrm{AA}$ & $6(6 \%)$ & $11(11 \%)$ & Reference 1 & ----- \\
\hline GG & $\mathrm{AG}$ & $5 \quad(5 \%)$ & $4(4 \%)$ & $2.3(0.5-4.9)$ & 0.3 \\
\hline GG & GG & $1(1 \%)$ & $10(10 \%)$ & $0.18(0.01-1.8)$ & 0.1 \\
\hline GA & AA & $16(16 \%)$ & $26(26 \%)$ & $1.1(0.3-3.6)$ & 0.8 \\
\hline GA & $A G$ & $24(24 \%)$ & $24(24 \%)$ & $1.8(0.85-5.7)$ & 0.2 \\
\hline GA & GG & $5(5 \%)$ & $0(0 \%)$ & & \\
\hline AA & AA & $15(15 \%)$ & $13(13 \%)$ & $2.1(0.6-7.3)$ & 0.2 \\
\hline AA & $\mathrm{AG}$ & $22(22 \%)$ & $12(12 \%)$ & $3.36(0.9-11.3)$ & 0.04 \\
\hline AA & GG & $6(6 \%)$ & $0(0.0 \%)$ & & \\
\hline
\end{tabular}

calculated by Chi Square test; Adjusted OR=Odds Ratio was adjusted to the age, $95 \% \mathrm{CI}=95 \%$ confidence interval.

Relation of XPD Asp312Asn and XRCC1 A399G polymorphisms and clinicopathological parameters of the $\mathrm{BC}$ patients

The association between genotypes and clinical characteristics of breast cancer patients were analyzed using six clinicopathological parameters; age, primary tumor size, presence of lymph node metastasis, AJCC stage tumor grade, and histological type 
(modified Bloom-Richardson score) Both XPD Asp312Asn and XRCC1 A399G polymorphisms didn't show any association with the clinical characteristics of disease among breast cancer patients (Table 6,7)

Table 6: Association of XPD Asp312Asn polymorphism with clinical characteristics.

\begin{tabular}{|c|c|c|c|c|c|}
\hline \multirow[t]{2}{*}{ Parameters } & \multirow[t]{2}{*}{$\bar{n}$} & \multicolumn{4}{|c|}{ XPD Asp312Asn polymorphism genotypes } \\
\hline & & GG n $(\%)$ & $\begin{array}{l}\text { GA/AA } \\
\text { n }(\%)\end{array}$ & p-value & $\begin{array}{l}\text { Adjusted OR } \\
(95 \% \mathrm{CI})\end{array}$ \\
\hline Patients & 100 & 12 & 88 & ------ & \\
\hline Age (years) & & & & & $0.6(0.17-1.17)$ \\
\hline$\leq 50$ & 67 & $7(58.3 \%)$ & $60(68.2 \%)$ & & \\
\hline $51-60$ & 33 & $5(41.7 \%)$ & $28(31.8 \%)$ & 0.49 & \\
\hline Lymph node status & & & & & $2(0.5-7.1)$ \\
\hline N0 & 52 & $8(66.7 \%)$ & $44(50 \%)$ & 0.2 & \\
\hline N1 & 48 & $4(33.3 \%)$ & $44(50 \%)$ & & \\
\hline Tumor size & & & & & $1.2(0.2-5.9)$ \\
\hline $\mathrm{T} 1 \& \mathrm{~T} 2$ & 81 & $10(83.3 \%)$ & $71(80.7 \%)$ & & \\
\hline T3 \&T4 & 19 & $2(16.7 \%)$ & $17(19.3 \%)$ & 0.8 & \\
\hline AJCC pathological stage & & & & & $1.7(0.3-8.6)$ \\
\hline I\&II & 75 & $10(83.3 \%)$ & $65(73.9 \%)$ & & \\
\hline III\&IV & 25 & $2(16.7 \%)$ & $23(26.1 \%)$ & 0.4 & \\
\hline Histological Grade & & & & & $1.1(0.2-4.9)$ \\
\hline I\&II & 72 & $9(75 \%)$ & $63(71.6 \%)$ & & \\
\hline III & 28 & $3(25 \%)$ & $25(28.4 \%)$ & 0.8 & \\
\hline
\end{tabular}

Table 7: Association of XRCC1 A399G polymorphism with clinical characteristics

\begin{tabular}{|c|c|c|c|c|c|}
\hline \multirow[t]{2}{*}{ Parameters } & \multirow[t]{2}{*}{$n$} & \multicolumn{4}{|c|}{ XRCC1 A399G polymorphism genotypes } \\
\hline & & $\begin{array}{l}\mathrm{AA} \\
\mathrm{n}(\%)\end{array}$ & $\begin{array}{l}\mathrm{AG} / \mathrm{GG} \\
\mathrm{n}(\%)\end{array}$ & p-value & $\begin{array}{l}\text { Adjusted OR } \\
(95 \% \mathrm{CI})\end{array}$ \\
\hline Patients & 100 & 37 & 63 & ------ & \\
\hline Age (years) & & & & & $0.49(0.19-1.24)$ \\
\hline$\leq 50$ & 67 & $21(56.7 \%)$ & $46(73 \%)$ & 0.09 & \\
\hline$\overline{5} 1-60$ & 33 & $16(43.3 \%)$ & $17(26.9 \%)$ & & \\
\hline Lymph node status & & & & & $0.57(0.23-1.4)$ \\
\hline No & 52 & $16(43.3 \%)$ & $36(57.1 \%)$ & 0.1 & \\
\hline N1 & 48 & $21(56.7 \%)$ & $27(42.9 \%)$ & & \\
\hline Tumor size & & & & & \\
\hline $\mathrm{T} 1 \& \mathrm{~T} 2$ & 81 & $29(78.3 \%)$ & $52(82.5 \%)$ & 0.6 & $0.77(0.25-2.3)$ \\
\hline $\mathrm{T} 3 \& \mathrm{~T} 4$ & 19 & $8(21.7 \%)$ & $11(17.5 \%)$ & & \\
\hline AJCC pathological stage & & & & 0.7 & $0.4(0.2-1.8)$ \\
\hline I\&II & 75 & $26(70.3 \%)$ & $49(77.8 \%)$ & & \\
\hline III\&IV & 25 & $11(29.7 \%)$ & $14(22.2 \%)$ & & \\
\hline Histological Grade & & & & & $1.1(0.4-2.9)$ \\
\hline I\&II & 72 & $27(72.9 \%)$ & $45(71.4 \%)$ & & \\
\hline III & 28 & $10(27.1 \%)$ & $18(28.6 \%)$ & 0.8 & \\
\hline
\end{tabular}

x calculated by Chi Square test; Adjusted OR=Odds Ratio was adjusted to the age, $95 \% \mathrm{CI}=95 \%$ confidence interval. 

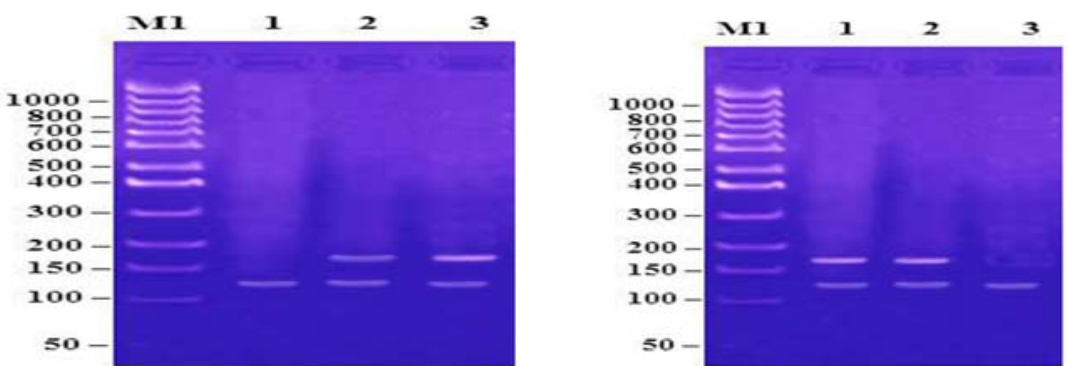

Fig. (1): Representative results for XPD Asp312Asn polymorphism by the ARMS method. Left gel for A genotype, right for G genotype Lane M, marker, lane 1, GG, lane 2, AG, lane 3, AA.

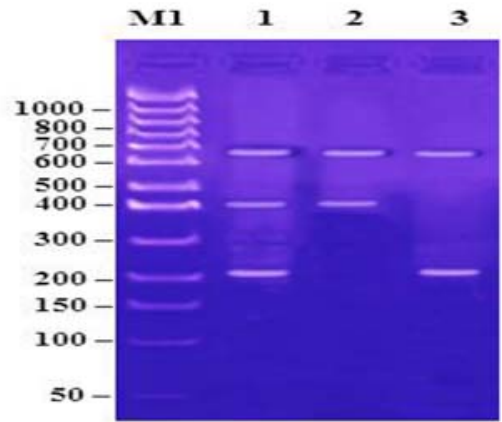

Fig. (2): Representative results for XRCC1 Arg399Gln polymorphism by the PCRCTPP method. Lane M, marker, lane 1, A/G, lane 2, GG, lane 3, AA.

\section{DISCUSSION}

One of the most commonly diagnosed cancers over the world is the Breast cancer, but its etiology is still largely unknown. Several environmental factors, as radiation, diet, smoking, and endogenous or exogenous estrogens, are associated with DNA damage. Unrepaired or misrepaired DNA results in gene mutations, chromosomal alterations, genomic instability and carcinogenesis $^{[19]}$. Earlier studies have demonstrated a strong association of higher levels of DNA damage and deficient DNA repair capacity in breast cancer patients ${ }^{[20,21]}$. Genetic polymorphisms on DNA repair genes are very common events, and there are conflicting reports on the influence of these polymorphisms on DNA repair capacity and cancer susceptibility ${ }^{\text {[22- }}$ 24].

The cause of breast cancer is complicated and can not be explained by means of only a single selected marker. Therefore, the goal of the 
present study was to examine the relation of two DNA repair genes XPD and XRCC1 polymorphisms with the risk of $\mathrm{BC}$ in Eastern Egyptian females .Also to determine the gene-gene interaction aiming to increase our understanding of the interaction between potential carcinogenic environmental exposure and genetic factors in the pathogenesis and predisposition to $\mathrm{BC}$ disease risk.

As regard to XPD codon 312 polymorphism, our results revealed that the frequencies of AA genotypes and $A$ allele were significantly higher in the breast cancer patients than in the normal individuals ( $\mathrm{p} \leq 0.003, \mathrm{p} \leq 0.002$ respectively). It was also found that participants homozygous Asn at XPD Asp312Asn had 3.5-fold higher risk of breast cancer.

Our findings are consistent with the results of Zhang et al. (2005) ${ }^{[25]}$ who reported that XPD AA genotypes were significantly different between BC patients and control group in Chinese population. Another study in Taiwanese patients by Wang et al. (2010) ${ }^{[26]}$ stated that the heterozygotes and homozygotes of the A allele of XPD asp312asn associated with BC development. Also, in France ${ }^{[27]}$ a study demonstrated an increase in the risk of breast cancer in individual heterozygous for ERCC2 (XPD) Asp312Asn in women receiving menopause substitution treatment.

However, a study by Kuschel et al. (2005) $)^{[28]}$ reported no evidence of association of ERCC2(XPD) polymorphism and breast cancer risk. Our results supported an African American study who found that subjects with an Asp-Asn or Asn-Asn polymorphic type in codon 312 of XPD had elevated levels of PAHDNA adducts compared to subjects with Asp-Asp genotype ${ }^{\text {[29] }}$.

$$
\text { As regards }
$$

XRCC1 polymorphism in the present study, the frequency of $\mathrm{G}$ (mutant) allele was $37.5 \%$ in $\mathrm{BC}$ patients and $30 \%$ in controls. However, this difference did not show statistical significant difference between patients and control groups $(\mathrm{P}=0.06)$. The homozygous mutant genotype (GG) and the heterozygous (AG) genotype showed no significant difference between patients and control groups $(\mathrm{p}=0.3)$ and $(\mathrm{p}=0.07)$.

Our results are consistent with the results of previous studies who found no significant role for XRCC1 Arg399Gln polymorphic variants in breast carcinogenesis ${ }^{\text {[30- 34] }}$

Furthermore, contrary to our results, Chacko et al. (2005) ${ }^{[35]}$, and Syamala et al. (2009) ${ }^{[36]}$, found an increased risk for sporadic breast cancer in Indian individuals with 399Gin allele of the XRCC1 .However, Dull et al.(2001) ${ }^{[37]}$ found a correlation between XRCC1(A allele) codon 399 polymorphism and breast cancer susceptibility in African-American women, but not in Caucasian women. Also, studies on Asian populations ${ }^{[38-40]}$ provided an evidence of significant association between XRCC1 $399 \quad$ Arg homozygosity and $\mathrm{BC}$ susceptibility. A study by Zipprich et al. (2010) ${ }^{[41]}$ reported that although the main effects of the genotype XRCC1 were not significantly associated with familial cancer risk, the XRCC1 399A may alter mRNA expression and DNA repair phenotype. 
Despite these inconsistent findings, which could be explained by ethnic factors or interaction between genetic and environmental factors, functional significance of polymorphism in XRCC1 gene is evident $^{[42-44]}$.

Regarding the association of clinical characteristics and different genotypes in breast cancer patients, our results showed no association between both XPD Asp312Asn and XRCC1 A399G polymorphisms and the clinical characteristics of disease. This data is consistent with results of Syamala et al.(2009) ${ }^{[36]}$ in their study on XRCC1 codon 399 polymorphism in sporadic and familial breast cancer patients.

Although the effect of an individual SNP is generally small, it is believed that the genetic effect of combinations of functionally relevant SNPs may additively or synergistically contribute to increased breast cancer risk. So, we studied the combined polymorphism of XPD and XRCC1 genes. To the best of our knowledge, there are no previous reports available regarding the association between combined polymorphism of XPD and XRCC1 genes and breast cancer from Egypt. Our results revealed that only combination of $\mathrm{AA}(\mathrm{XPD})+\mathrm{AG}$ (XRCC1) might increase the risk of breast cancer (OR 3.36 CI 0.9 ---11.3) $(p \leq 0.04)$. However, these results need more investigation to study gene gene interactions and its relation to breast cancer susceptibility aiming to identify individuals at increased risk of breast cancer and develop preventive strategies .
In conclusion, our results suggest that AA genotype of XPD Asp 312 Asn polymorphism increased the risk of breast cancer.XPD gene is an important candidate gene for susceptibility to breast cancer. Also, gene-gene interaction between XPD(AA)+XRCC1(AG)

polymorphism may be associated with increased risk of breast cancer in Egyptian women.

Acknowledgments This study was funded with the support of academic research in Zagazig University Projects, Zagazig University. Postgraduate \& Research Affairs.

\section{REFERENCES}

1. Parkin DM., Bray F., Ferlay J (2005): Global cancer statistics. CA Cancer J. Clin ., 55:74-108.

2. Ibrahim AS et al. (2002): Cancer profile in Gharbiah, Egypt. Methodology and results. Cairo, Ministry of Health and Population Egypt and Middle East Cancer Consortium.

3. Elatar I (2001): Cancer registration, NCI Egypt. Cairo, Egypt, National Cancer Institute.

4. Hosny G., Elkaffas SM (2002): A prediction model for the incidence patterns of female breast cancers in Alexandria, Egypt. J. Egypt. Public Health Assoc., 77(3-4): 329-45.

5. Hu JJ., Smith TR., Miller MS., Lohman K., Case LD (2002): Genetic regulation of ionizing radiation sensitivity and breast cancer risk. Environ. Mol. Mutagen., 39: 208-215.

6. Parshad R., Price FM., Bohr VA., Cowans KH., Zujewski 
JA., Sanford KK (1996): Deficient DNA repair capacity, a predisposing factor in breast cancer. Br. J. Cancer Jul.74(1):15.

7. Debniak, T., Scott, RJ., Huzarski, T., Byrski T., Masojc B., van de Wetering T., Serrano-Fernandez P., Gorski B., Cybulski C., Gronwald J., Debniak B., Maleszka R., Kladny J., Bieniek A., Nagay L., Haus O., GrzybowskaE., Wandzel P., Niepsuj S., Narod S.A. and Lubinski J(2006) :XPD common variants and their association with melanoma and breast cancer risk. Breast Cancer Res. Treat., 98: 209-215,

8. de Boer JG

:Polymorphisms in DNA repair and environmental interactions. Mutat Res.,509:201-10.

9. Berwick M., Vineis $P$ (2000): Markers of DNA repair and susceptibility to cancer in humans: an epidemiologic review. J. Natl. Cancer Inst., 92:874-97.

10. Laine JP., Mocquet V., Bonfanti M., Braun C., Egly JM., Brousset P (2007): Common XPD (ERCC2) polymorphisms have no measurable effect on nucleotide excision repair and basal transcription. DNA Repair (Amst)6:1264-70.

11. Shen MR., Jones IM. And Mohrenweiser H (1998): Non: conservative amino acid substitution variants exist at polymorphic frequency in DNA repair genes in healthy humans. Cancer Res., 58: 604-608.
12. Lunn RM., Helzlsouer KJ., Parshad R., Umbach DM., Harris EL., Sanford KK. and Bell DA (2000): XPD polymorphisms: effects on DNA repair proficiency. Carcinogenesis 21: 551-555.

13. Caldecott KW., Aoufouchi S., Johnson P., Shall S (1996): XRCC1 polypeptide interacts with DNA polymerase beta and possibly poly (ADP-ribose) polymerase, and DNA ligase III is a novel molecular 'nick-sensor' in vitro. Nucleic Acids Res., 24:4387-4394.

14. Hu JJ., Mohrenweiser HW., Bell DA( 2002): Symposium overview: genetic polymorphisms in DNA repair and cancer risk. Toxicol. Appl. Pharmacol., 185:64-73.

15. Bloom HI., Richardson WW (1957): Histological grading and prognosis. Br. J. Cancer 11:359377.

16. Breast. AJCC (2002): Cancer Staging Manual. In: American Joint Committee on Cancer. 6th ed. Springer, New York pp 171180.

17. Rybicki BA., Conti DV., Moreira A., Cicek M., Casey G., Witte JS (2004): Repair Gene XRCC1 and XPD Polymorphisms and Risk of Prostate Cancer. Cancer Epidemiol. Biomarkers Prev January. 13; 23.

18. Ito H., Matsuo K., Hamajima N., MitsudomiT (2004) :Geneenvironment interactions between the smoking habit and polymorphisms in the DNA repair genes, APE1 Asp148Glu 
and XRCC1 Arg399Gln, in Japanese lung cancer risk Carcinogenesis 25 (8): 13951401.

19. Jemal A., Tiwari RC., Murray T., Ghafoor A., Samuels A., Ward E., Feuer EJ. and Thun MJ (2004) :Cancer statistics, CA Cancer J. Clin., 54: 8-29.

20. Helzlsouer KJ., Harris EL., Parshad R (1996): DNA repair proficiency: potential susceptibility factor for breast cancer. J. Natl. Cancer Inst., 88:754-755.

21. Jyothish B., Ankathil R., Chandini R. et al., (1998): DNA repair proficiency: a potential marker for identification of high risk members in breast cancer families. Cancer Lett 124:9-13.

22. Matullo G., Palli D., Peluso M., et al. (2001): $\mathrm{XRCC} 1, \mathrm{XRCC} 3$, XPD gene polymorphisms, smoking and (32)P-DNA adducts in a sample of healthy subjects. Carcinogenesis 22:1437-1445.

23. Clarkson SG., Wood RD(2005): Polymorphisms in the human XPD (ERCC2) gene, DNA repair capacity and cancer susceptibility: an appraisal. DNA Repair (Amst) 4:1068-1074.

24. Pachkowski BF., Winkel S., Kubota Y. et al., (2006): XRCC1 genotype and breast cancer: functional studies and epidemiologic data show interactions between XRCC1 codon 280 His and smoking. Cancer Res., 66:2860-2868.

25. Zhang L., Zhang Z., and Yan W (2005): Single nucleotide polymorphisms for DNA repair genes in breast cancer patients. Clin. Chim. Acta359: 150-155 .

26. Wang HC., Liu CS., Wang HC., Tsai R Y., Tsai CW., Wang RF., Chen YS., Chiu CF., Bau DT., Huang CY( 2010): Significant Association of XPD Asp312Asn Polymorphism with Breast Cancer in Taiwanese Patients Chinese Journal of Physiology 53, prepublication Ahead of Print.

27. Bernard-Gallon D., Bosviel R., Delort L., Fontana L., ChamouxA., Rabiau N., Kwiatkowski F., Chalabi N., Satih S. and Bignon YJ (2008): DNA repair gene ERCC2 polymorphisms and associations with breast and ovarian cancer risk. Mol. Cancer 7: 36.

28. Kuschel B., Chenevix-Trench G., Spurdle AB., Chen X., Hopper JL., Giles GG., McCredie M., Chang-Claude J., Gregory CS., Day NE., Easton DF., Ponder BA., DunningAM. and Pharoah PD (2005):Common polymorphisms in ERCC2 (Xeroderma pigmentosum D) are not associated with breast cancer risk. Cancer Epidemiol.Biomarkers Prev., 14: 1828-1831.

29. Smith TR., Levine EA., Freimanis RI., Akman SA., Allen GO., Hoang KN., LiuMares W. and Hu JJ (2008): Polygenic model of DNA repair genetic polymorphisms in human breast cancer risk. Carcinogenesis 29: 2132-2138.

30. Figueiredo JC., Knight JA., Briollais L. et al., (2004): Polymorphisms XRCC1-R399Q 
and XRCC3-T241M and the risk of breast cancer at the Ontario site of the Breast Cancer Family Registry. Cancer Epidemiol. Biomarkers Prev., 13:583-591.

31. Shu XO., Cai Q., Gao YT. et al., (2003): A population-based case control study of the Arg399Gln polymorphism in DNA repair gene XRCC1 and risk of breast cancer. Cancer Epidemiol. Biomarkers Prev., 12:1462-1467.

32. Smith TR., Miller MS., Lohman K. et al., (2003): Polymorphisms of XRCC1 and XRCC3 genes and susceptibility to breast cancer. Cancer Lett 190:183-190.

33. Deligezer U.,Dalay $\mathbf{N}(\mathbf{2 0 0 4 )}$ : Association of the XRCC1 gene polymorphisms with cancer risk in Turkish breast cancer patients. Exp. Mol. Med., 36:572-575

34. Shen J., Gammon MD., Terry MB. et al., (2005): Polymorphisms in XRCC1 modify the association between polycyclic aromatic hydrocarbonDNA adducts, cigarette smoking, dietary antioxidants, and breast cancer risk. Cancer Epidemiol. Biomarkers Prev., 14:336-342.

35. Chacko P., Rajan B., Joseph T. et al., (2005): Polymorphisms in DNA repair gene XRCC1 and increased genetic susceptibility to breast cancer. Breast Cancer Res. Treat., 89:15-21.

36. Syamala VS., SyamalaV., Sreedharan H., Raveendran PB., KuttanR., Ankathil R (2009): Contribution of XPD (Lys751Gln) and XRCC1 (Arg399Gln) Polymorphisms in Familial and Sporadic Breast
Cancer Predisposition and Survival: An Indian Report Pathol. Oncol. Res., 15:389-397.

37. Duell EJ., Millikan RC., Pittman GS. et al., (2001): Polymorphisms in the DNA repair gene $\mathrm{XRCC1}$ and breast cancer. Cancer Epidemiol. Biomarkers Prev., 10:217-222.

38. Kim SU., Park SK., Yoo KY et al. (2002): XRCC1 genetic polymorphism and breast cancer risk. Pharmacogenetics 12:335338.

39. Clarkson SG., Wood RD. (2005): Polymorphisms in the human XPD (ERCC2) gene, DNA repair capacity and cancer susceptibility: an appraisal. DNA Repair (Amst)4:1068-74.

40. Wang Y., Spitz MR., Zhu Y et al.( 2003): From genotype to phenotype: correlating XRCC1 polymorphisms with mutagen sensitivity. DNA Repair (Amst)2:901-8.

41. 41. Zipprich J., Terry M B., Brandt-Rauf P., Freyer GA., LiaoY., AgrawalM., Gurvich I., Senie R., Santella RM (2010): XRCC1 polymorphisms and breast cancer risk from the New York Site of the Breast Cancer Family Registry: A family-based case-control study J. Carcinog., 9:4.

42. Matullo G., Palli D., Peluso M et al., (2001): XRCC1, XRCC3, XPD gene polymorphisms, smoking and (32)P-DNA adducts in a sample of healthy subjects. Carcinogenesis 22:1437-1445.

43. Lunn RM., Langlois RG., Hsieh LL et al,.(1999): XRCC1 polymorphisms: effects on 
aflatoxin B1-DNA adducts and glycophorin A variant frequency. Cancer Res., 59:2557-2561.

44. Hu JJ., Smith TR., Miller MS et al., (2001): Amino acid substitution variants of APE1 and XRCC1 genes associated with ionizing radiation sensitivity. Carcinogenesis 22:917-922. 


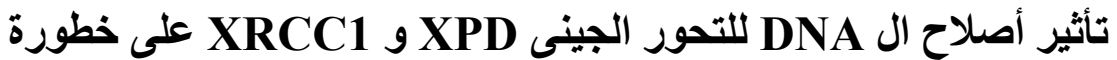 سرطان الثى فى المريضات المصريات
}

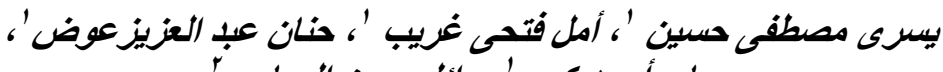

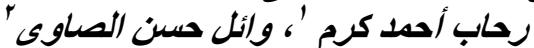 \\ قسم الكيمياء الحيوية الطبية' 'و قسم علاج الاورام 'بكلية الطب جامعة الزقازيق
}

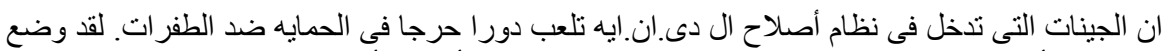

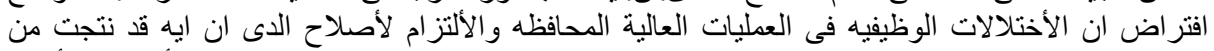

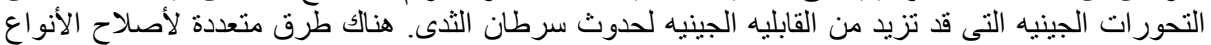

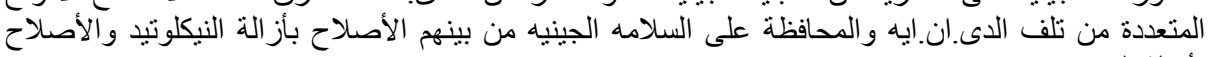

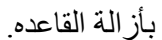

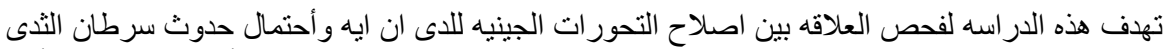

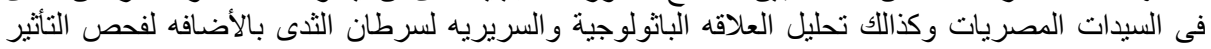

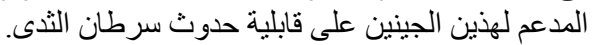

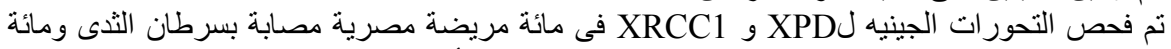

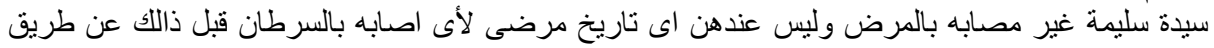

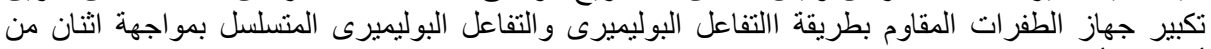

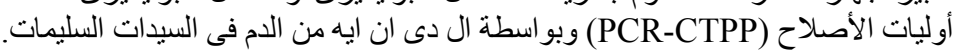

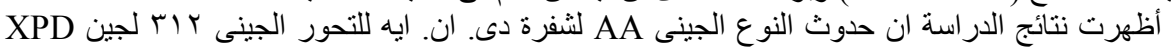

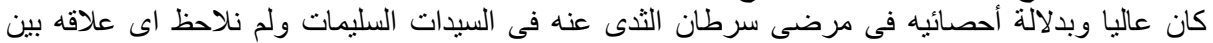

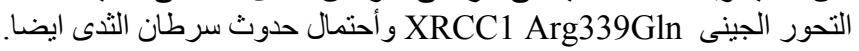

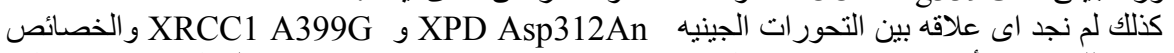

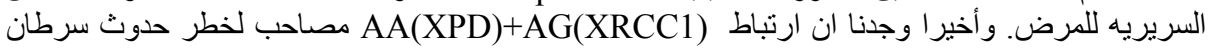

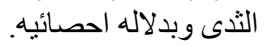

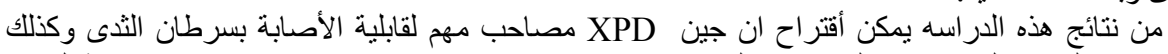

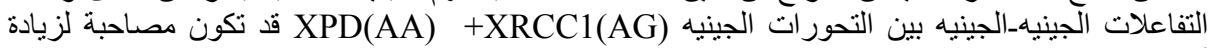
أحتمال حدوث سرطان الثذى في السيدات المصريات. 